\title{
"Vom iranischen Sozialrebellen zum sowjetischen Stalinpreisträger. Eine multiple Biographie ». SGMOIK Bulletin, (May 1999), pp. 4-10.
}

\section{Rudi Matthee}

\section{(2) OpenEdition}

1 Journals

\section{Édition électronique}

URL : http://journals.openedition.org/abstractairanica/35449

DOI : 10.4000/abstractairanica.35449

ISSN : 1961-960X

Éditeur :

CNRS (UMR 7528 Mondes iraniens et indiens), Éditions de l'IFRI

\section{Édition imprimée}

Date de publication : 15 mai 2002

ISSN : 0240-8910

\section{Référence électronique}

Rudi Matthee, « « Vom iranischen Sozialrebellen zum sowjetischen Stalinpreisträger. Eine multiple Biographie ». SGMOIK Bulletin, (May 1999), pp. 4-10. », Abstracta Iranica [En ligne], Volume 23 | 2002, document 178, mis en ligne le 08 février 2010, consulté le 25 septembre 2020. URL : http:// journals.openedition.org/abstractairanica/35449; DOI : https://doi.org/10.4000/abstractairanica. 35449

Ce document a été généré automatiquement le 25 septembre 2020.

Tous droits réservés 


\title{
«Vom iranischen Sozialrebellen zum sowjetischen Stalinpreisträger. Eine multiple Biographie ». SGMOIK Bulletin, (May 1999), pp. 4-10.
}

\author{
Rudi Matthee
}

1 This short piece recapitulates the eventful career of the poet Abu'l Qāsem Lāhūtī. Born in Kermānšăh in 1887, he was forced to flee Iran three times on account of his revolutionary convictions, first to Baghdad for alleged murder, then to Istanbul following WWI, and finally and definitively to Russia in 1922. In Russia, where he died in 1957, he was inducted into the hall of fame of ideologically correct poets, winning the Stalin Prize. Since its independence, Persian-speaking Tajikistan has celebrated him as a national champion of the proletariat. In Iran, by contrast, he was erased from national literary memory.

\section{INDEX}

Thèmes : 4.3. Histoire de l'Iran moderne (à partir de 1905)

\section{AUTEURS}

RUDI MATTHEE

Université de Delaware (États-Unis) 